\title{
Hypsometric demography of Kosovo: the distribution of Kosovo population by altitude
}

\author{
Rizah Murseli ${ }^{*}$ and Hazer Dana \\ The original version of this article was revised to add a missing reference to the reference list
}

\begin{abstract}
This paper attempt to analyze how population dynamics changed in Kosovo through altitude and time. Altitude is one of the fundamental physiographic factor that determine the vertical distribution of human activities on earth. Altitude also determine the availability of natural resources because by increasing altitude somehow decreases the total surface of land available for agriculture, development and as well as increases the environmental constrains and restrictions in the use of land due to the topography, environmental regulations and policies. In order to concrete the research, Kosovo territory is zoned vertically into six hypsometric levels. Using digital Elevation Model for Kosovo the hypsometric zones are as follows: $<500 ; 500-750 ; 750-1000 ; 1000-1250 ; 1250-1500$ and $>1500 \mathrm{~m}$. Also, population changes are analyzed through six population censuses realized in Kosovo after the second WW, starting from 1948, 1953, 1961, 1971, 1981 and 2011. The basic analyzed unit is settlement as a centroid.
\end{abstract}

Keywords: Population, Density, Vertical zone, Index, Agricultural land, GIS

\section{Background}

Altitude determine the development of many human activities, among them the human settlement. By increasing altitude, the total amount of geographic area reduces and with it gradually reduce the opportunities for the development of settlements and life in general.

Among the factors that affects the altitude are: physiographic, environmental, biological and socio-economic factors. The importance of physiographic factors related to the fact that many human developments in their historical evolution have been conditioned by the factors such very early human settlements are located in lowlands and near rivers where the water and fertile soil were present. e.g. Ulpiana, an ancient city of Dardania (present Kosovo) extended to $577 \mathrm{~m}$ above sea level, in front of the Graçanka river and mainly in alluvial soil-fertile agricultural land. While biological factors in early development have played an important role in population or depopulation of geographical area due to the spread of infectious

\footnotetext{
*Correspondence: rizah.murseli@gmail.com University of Prishtina, Mother Teresa Street No Number, 10000 Prishtina, Kosovo
}

diseases, e.g. as malaria, cholera, etc. Altitude affects as well the socio-economic aspects of human development entirely, and is very much influential under development society rather than developed society. Altitude determine or complicate conditions of socio-economic development and human influence on normal life development, for e.g. the greater is the altitude, the less arable land is in disposal, the terrain has a high degree of slop, major centers are difficult to access, as well as the spread of innovations are very slow.

\section{Methods}

In this research are analyzed several data sets, ranging from elevation of Kosovo, population, settlements and population in different periods, as well as agricultural land in relations with hypsometry, population and settlements etc. Data on altitude or hypsometry are provided by Global Digital Elevation Model (MDR) called "Aster GDEM" 30 m/px (ASTER GDEM 2011). Then the Kosovo territory is zoned vertically in 6 hypsometric zones, ranging from $<500,500-750,750-1000,1000-1250$, $1250-1500$, and $>1500 \mathrm{~m}$. While demographic data are from the centroid of Kosovo settlements, namely 
according to the census years (1948, 1953, 1961, 1971, 1981, 2011). There is also the estimated population census of 1991 which was held during the occupation time and was rejected by Kosovo population, manly by Albanians due to the fear and risk of manipulation and its political purposes. This estimated or irregular census is not part of this research for reason mention above and its incompatibility that might effects this research.
The data on agricultural land are taken from dataset of agricultural land suitability divided into eight classes according to present Kosovo national classification system (Ministry of Agriculture, Forestry and Rural Development). Through applications of GIS data for the population are divided by hypsometric zones and other variables, which by various methods as spatial analysis, map algebra, historical method, comparative statistics are analyzed

Table 1 Vertical zoning of Kosovo surface (by authors)

\begin{tabular}{|c|c|c|c|c|c|}
\hline No. & Vertical zones & Hypsometric zones (m) & Geographic landscape & Area $\mathrm{km}^{2}$ & $\%$ \\
\hline $\mathrm{Z1}$ & Low & $<500$ & Flat ground landscape & 1763.10 & 16.17 \\
\hline Z2 & Medium & $500-750$ & Field-valley landscape & 4481.10 & 41.09 \\
\hline Z3 & Average high & $750-1000$ & Valley-hilly landscape & 2350.71 & 21.56 \\
\hline Z4 & High & $1000-1250$ & Mountainous landscape & 912.60 & 8.37 \\
\hline Z5 & Very high & $1250-1500$ & Mountainous-alpine landscape & 513.75 & 4.71 \\
\hline Z6 & Extremely high & $>1500$ & Alpine landscape & 883.90 & 8.11 \\
\hline 6 & Total & & - & $10,905.17$ & 100.00 \\
\hline
\end{tabular}

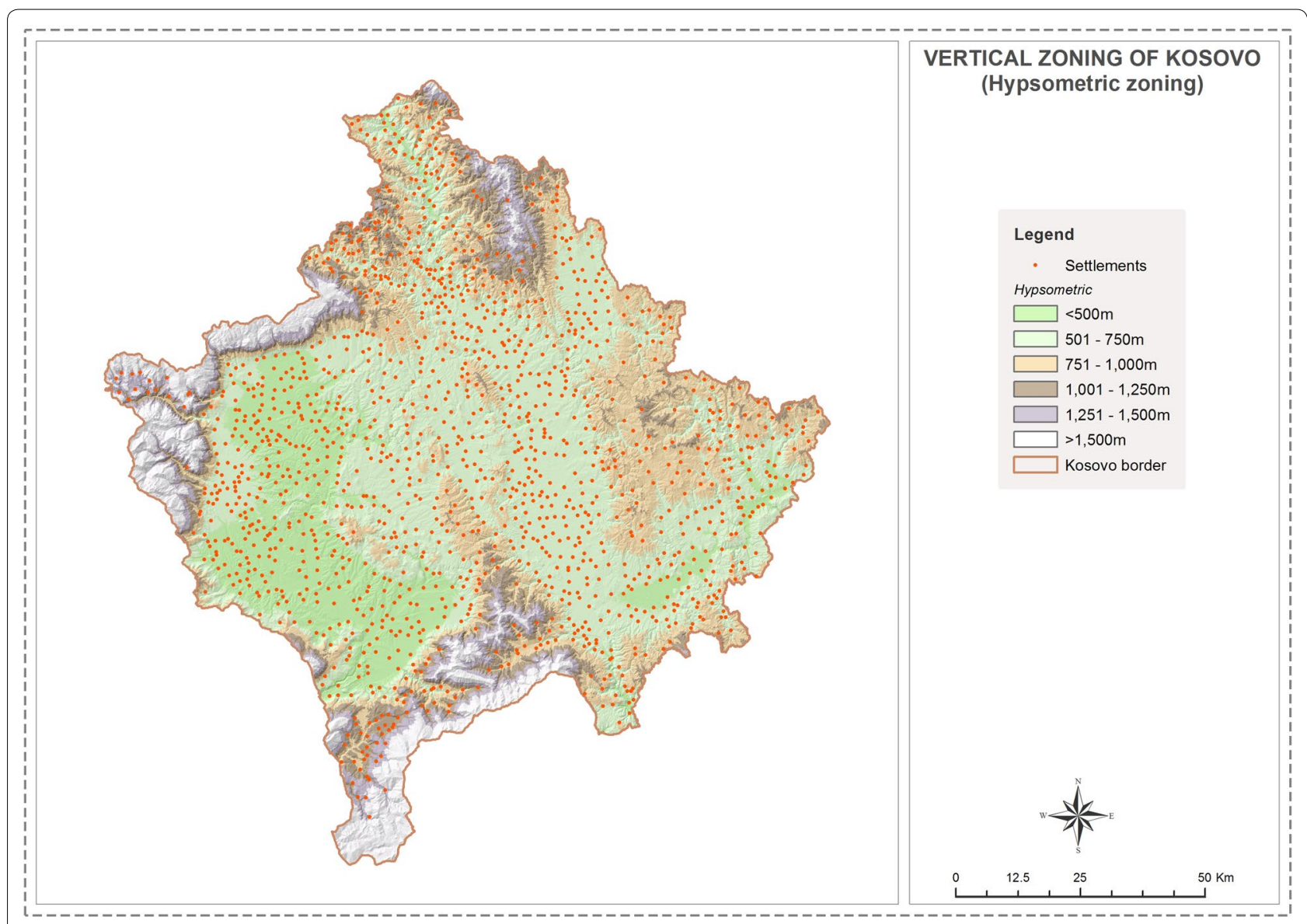

Fig. 1 Vertical zoning of Kosovo (by authors) 
these three key variables and then acquired results are presented in this paper.

\section{Results}

\section{Hypsometry-vertical zoning}

For the purposes of this survey, Kosovo is divided into six vertical zones, relying mainly on a complex factor, such as morphological factors, micro climate, vegetation, agronomic, communication and anthropologic. So, while analyzing the above-mentioned factors in Kosovo circumstances zoning is divided as in Table 1 .

The vast majority of Kosovo's surface is mostly flat ground, namely the $57.26 \%$ consists of lowland landscape coupled with some gentle river valleys, where $16.17 \%$ belong to first hypsometric zone $<500 \mathrm{~m}$ and $41.09 \%$ belong to the hypsometric zone of 500-750 $\mathrm{m}$, and zone from 750 to $1000 \mathrm{~m}$ represents $21.56 \%$ of entire territory of Kosovo. Mountainous terrain or zone $>1000 \mathrm{~m}$ respectively comprise $21.19 \%$ of the total area of Kosovo, of which $8.37 \%$ lie in the hypsometric zone $1000-1250 \mathrm{~m}$, from 1250 to $1500 \mathrm{~m}$ are $4.71 \%$, and $8.11 \%$ are $>1500 \mathrm{~m}$ (Fig. 1).

\section{Hypsometry and agricultural land}

Agricultural land in Kosovo is divided into eight classes of suitability, from which 1-4 are protected by law and intended for the purpose of agricultural production and it has a fund of $5183.59 \mathrm{~km}^{2}$ or $47.53 \%$ of the total territory of Kosovo. In general, with increasing altitude decreases the fund of agricultural land due to natural conditions. The largest fund of agricultural land by hypsometric zones is closely linked with the largest fund of land that lies in the respective zone, so in the hypsometric zone $500-750 \mathrm{~m}$ are $58.59 \%$ of agricultural land, while $30.03 \%$ are under $<500 \mathrm{~m}$, which means that $88.62 \%$ of agricultural land of classes $1-4$ lies in these two first hypsometric zones. While only $9.38 \%$ lies in $750-1000 \mathrm{~m}$ of hypsometric zone, and only $2.05 \%$ lies $>1000 \mathrm{~m}$.

Demographic development in settlements of Kosovo, from the population censuses of 1948 to 2011 the population density on agricultural land has grown consistently as follows: in the hypsometric zone $<500 \mathrm{~m}$ population density on agricultural land of class 1-4 Increase from $121 \mathrm{inh} / \mathrm{km}^{2}$ to $324 \mathrm{inh} / \mathrm{km}^{2}$, in the

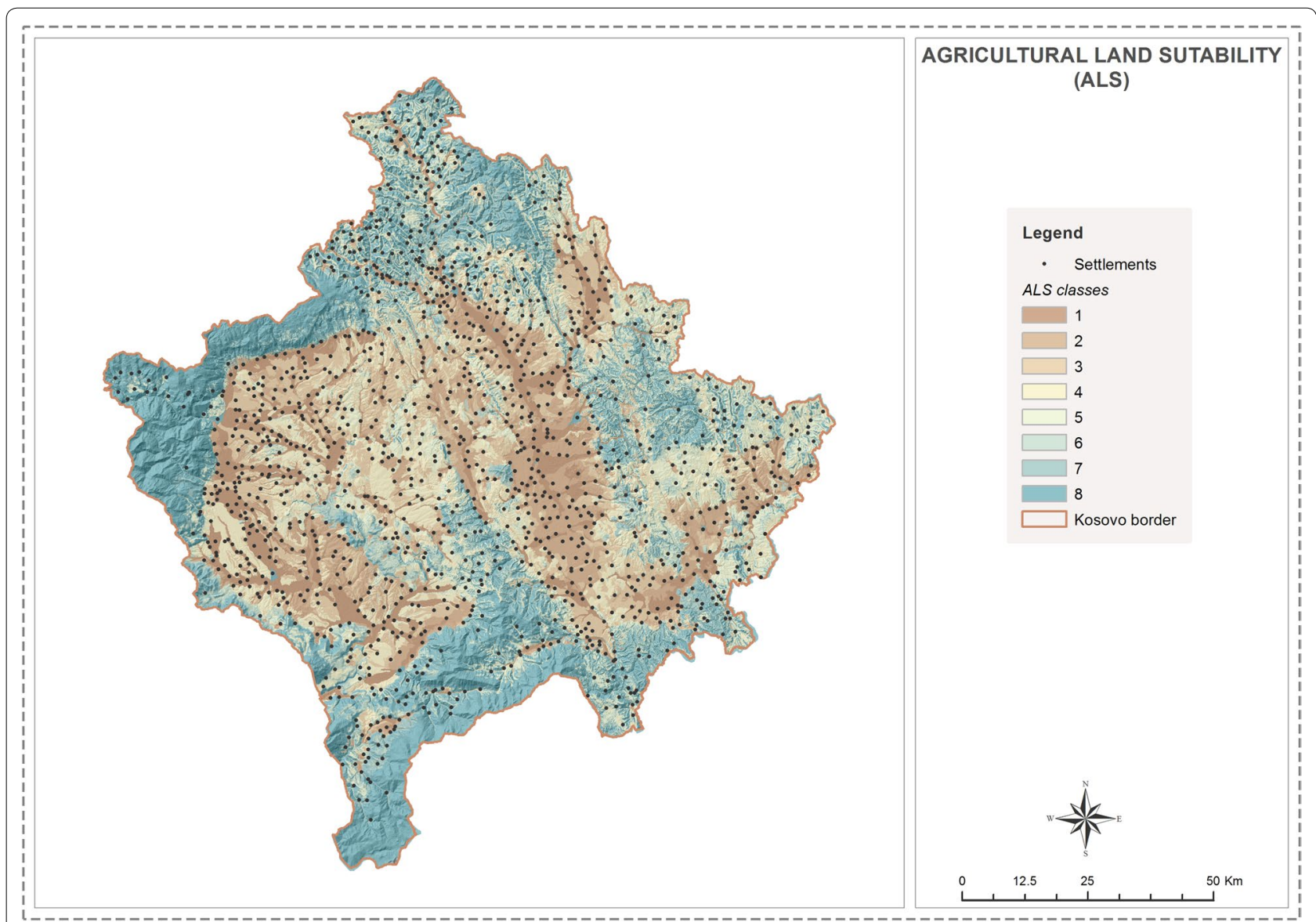

Fig. 2 Agricultural land suitability map of Kosovo (by authors) 


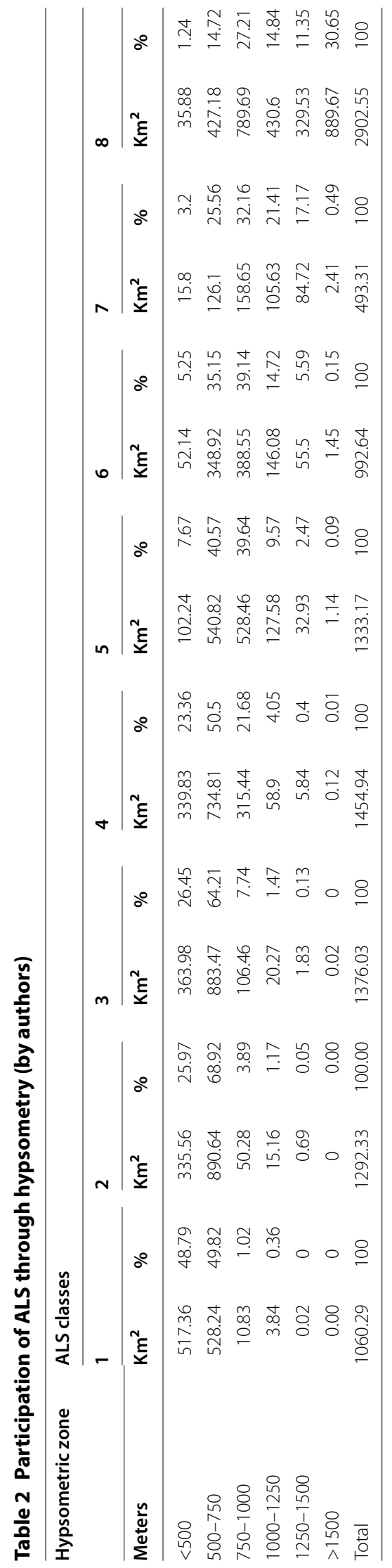


Table 3 Settlements by population size and hypsometry (by authors)

\begin{tabular}{|c|c|c|c|c|c|c|c|c|c|}
\hline \multirow[t]{2}{*}{ Period } & \multirow[t]{2}{*}{ Hypsometry (metric) } & \multicolumn{6}{|c|}{ Classification of settlements by population sizes, inhabitants (inh.) } & \multirow[t]{2}{*}{ No } & \multirow[t]{2}{*}{$\%$} \\
\hline & & $<500$ & $500-2500$ & $2500-5000$ & $5000-25,000$ & $25,000-50,000$ & $>50,000$ & & \\
\hline \multirow[t]{8}{*}{1948} & $<500$ & 244 & 95 & - & 3 & - & - & 342 & 23.80 \\
\hline & $500-750$ & 477 & 277 & 2 & 6 & - & - & 762 & 53.03 \\
\hline & $750-1000$ & 172 & 52 & - & - & - & - & 224 & 15.59 \\
\hline & $1000-1250$ & 68 & 21 & - & - & - & - & 89 & 6.19 \\
\hline & $1250-1500$ & 14 & 5 & - & - & - & - & 19 & 1.32 \\
\hline & $>1500$ & 1 & - & - & - & - & - & 1 & 0.07 \\
\hline & Total & 976 & 450 & 11 & 9 & - & - & 1437 & 100.00 \\
\hline & $\%$ & 67.92 & 31.32 & 0.77 & 0.63 & - & - & 100.00 & - \\
\hline \multirow[t]{8}{*}{1953} & $<500$ & 228 & 111 & - & 3 & - & - & 342 & 23.80 \\
\hline & $500-750$ & 439 & 315 & 4 & 6 & - & - & 764 & 53.17 \\
\hline & $750-1000$ & 163 & 61 & - & - & - & - & 224 & 15.59 \\
\hline & $1000-1250$ & 63 & 24 & - & - & - & - & 87 & 6.05 \\
\hline & $1250-1500$ & 15 & 4 & - & - & - & - & 19 & 1.32 \\
\hline & $>1500$ & 1 & - & - & - & - & - & 1 & 0.07 \\
\hline & Total & 909 & 515 & 4 & 9 & - & - & 1437 & 100.00 \\
\hline & $\%$ & 63.26 & 35.84 & 0.28 & 0.63 & - & - & 100.00 & - \\
\hline \multirow[t]{8}{*}{1961} & $<500$ & 202 & 134 & 4 & 2 & 1 & - & 343 & 23.87 \\
\hline & $500-750$ & 394 & 355 & 8 & 3 & 3 & - & 763 & 53.10 \\
\hline & 750-1000 & 156 & 68 & - & - & - & - & 224 & 15.59 \\
\hline & $1000-1250$ & 62 & 25 & - & - & - & - & 87 & 6.05 \\
\hline & $1250-1500$ & 13 & 6 & - & - & - & - & 19 & 1.32 \\
\hline & $>1500$ & 1 & - & - & - & - & - & 1 & 0.07 \\
\hline & Total & 828 & 588 & 12 & 5 & 4 & - & 1437 & 100.00 \\
\hline & $\%$ & 57.62 & 40.92 & 0.84 & 0.35 & 0.28 & - & 100.00 & - \\
\hline \multirow[t]{8}{*}{1971} & $<500$ & 145 & 184 & 9 & 1 & 2 & - & 341 & 23.76 \\
\hline & $500-750$ & 323 & 420 & 11 & 6 & 2 & 1 & 763 & 53.17 \\
\hline & 750-1000 & 154 & 70 & - & - & - & - & 224 & 15.61 \\
\hline & $1000-1250$ & 56 & 31 & - & - & - & - & 87 & 6.06 \\
\hline & $1250-1500$ & 13 & 5 & 1 & - & - & - & 19 & 1.32 \\
\hline & $>1500$ & 1 & - & - & - & - & - & 1 & 0.07 \\
\hline & Total & 692 & 710 & 21 & 7 & 4 & 1 & 1435 & 100.00 \\
\hline & $\%$ & 48.22 & 49.48 & 1.46 & 0.49 & 0.28 & 0.07 & 100.00 & - \\
\hline \multirow[t]{8}{*}{1981} & $<500$ & 118 & 200 & 18 & 4 & 1 & 1 & 342 & 23.67 \\
\hline & $500-750$ & 280 & 450 & 24 & 8 & 2 & 3 & 767 & 53.08 \\
\hline & 750-1000 & 166 & 62 & - & - & - & - & 228 & 15.78 \\
\hline & $1000-1250$ & 59 & 29 & - & - & - & - & 88 & 6.09 \\
\hline & $1250-1500$ & 12 & 6 & 1 & - & - & - & 19 & 1.31 \\
\hline & $>1500$ & 1 & - & - & - & - & - & 1 & 0.07 \\
\hline & Total & 636 & 747 & 43 & 12 & 3 & 4 & 1445 & 100.00 \\
\hline & $\%$ & 44.01 & 51.70 & 2.98 & 0.83 & 0.21 & 0.28 & 100.00 & - \\
\hline \multirow[t]{8}{*}{2011} & $<500$ & 141 & 167 & 22 & 12 & 1 & 1 & 344 & 23.43 \\
\hline & $500-750$ & 303 & 424 & 44 & 14 & 4 & 2 & 791 & 53.88 \\
\hline & $750-1000$ & 204 & 23 & - & - & - & - & 227 & 15.46 \\
\hline & $1000-1250$ & 70 & 22 & 1 & - & - & - & 93 & 6.34 \\
\hline & $1250-1500$ & 6 & 5 & 1 & - & - & - & 12 & 0.82 \\
\hline & $>1500$ & 1 & - & - & - & - & - & 1 & 0.07 \\
\hline & Total & 725 & 641 & 68 & 26 & 5 & 3 & 1468 & 100.00 \\
\hline & $\%$ & 49.39 & 43.66 & 4.63 & 1.77 & 0.34 & 0.20 & 100.00 & - \\
\hline
\end{tabular}


hypsometric zone $500-750 \mathrm{~m}$ population density increased from $141 \mathrm{inh} / \mathrm{km}^{2}$ to $390 \mathrm{inh} / \mathrm{km}^{2}$, while in the third hypsometric zone or $750-1000 \mathrm{~m}$ population density has decreased from $160 \mathrm{inh} / \mathrm{km}^{2}$ to $96 \mathrm{inh} / \mathrm{km}^{2}$. Hypsometric zone $>1000 \mathrm{~m}$ due to the very small fund of agricultural land in spite of having very few inhabitants, the population density is high, for e.g. in hypsometric zone 1200-1500 m in 2011 lived 10,298 inh, while total agricultural land surface of classes $1-4$ is $8.38 \mathrm{~km}^{2}$ (Fig. 2; Table 2).

With the growth of the total population of Kosovo from one period to another one increases the average density of population which lies on agricultural land suitability of classes 1-4.

\section{Settlements and hypsometry}

Kosovo settlement are different in terms of territorial and demographic size. Change is evident in hypsometric scale and time and depending on the infringer's population and type, their number also varies according to the hypsometric zones and range size. On the threshold of hypsometric of the first and second zone or $<750 \mathrm{~m}$ lies the largest number of settlements where depending on the time period their numbers increase or decrease. Also, by increasing the number of overall population also varies the range size of settlements, such as in 1948 about $67 \%$ of settlements in Kosovo have been of size $<500$ inh, $31.21 \%$ of size $500-2500$ inh and only $1.38 \%$ of size 5000-25,000 inh and none settlement greater than 25,000 inh. Never the less the same situation is in census of 1953. This is mainly the period when Kosovo's economic base dominated by the primary sector, mainly extensive agriculture and forestry. While in the census of 1961 the majority of the settlements or $57.50 \%$ of them belonged to range size $<500$ inh, while $41.03 \%$ belongs to range sizes of $2500-5000$ inh, and only $0.63 \%$ or 9 settlements belonged to the group of settlements $5000-50,000$ inh, where 5 of them belonged to range size 5000-25,000 inh and only four settlements from 25,000 to 50,000 inh. By increasing the economic base of Kosovo, namely the increase of industrialization also increases the number of larger settlements and reduce the number of smallest, such as in the censuses of 1961 dominated the settlements size $<500$ inh with a number of 824 settlements. A decade later the number of settlements reduced to 688 , while the number of settlements from 500 to 2500 inh increased by $588-710$ representing the largest group of settlements in Kosovo. Growing marks, the settlements of range size $2500-5000$ inh increased by 12-21, group of settlements 5000 25,000 inh grow for two settlements, while it appeared for the first time the type of range size settlements $>50,000$ inh (Prishtina). In terms of hypsometric participation, it is the same situation almost since the first registration census. In the 1981 group of settlements with over 50,000 inh added the 3 settlements. Growing settlements marks in range size 500-25,000 inh while the range size settlements $<500$ inh continue to decline. The greater the degree of industrialization became increase the number of larger settlements, because the industry was concentrated in the larger cities where required largely amount of worker and also skilled worker.

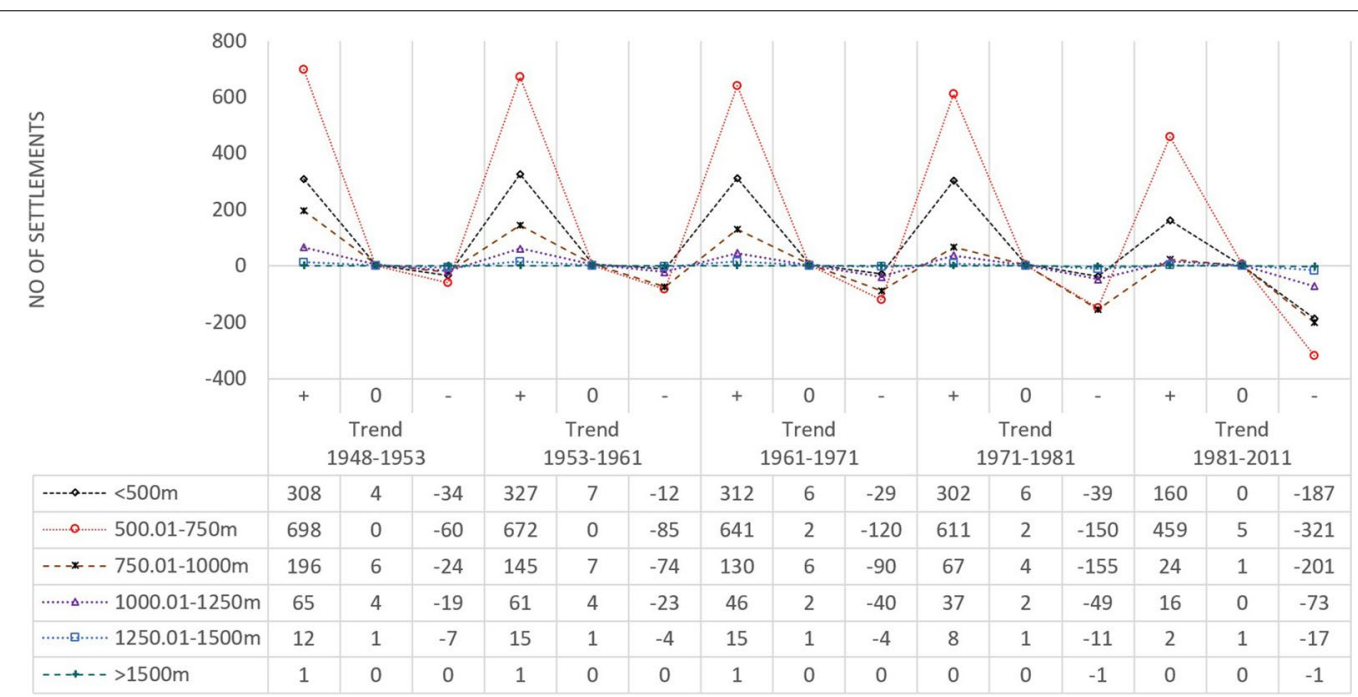

Fig. 3 Settlements with positive, negative and stagnant population trend according to hypsometry (by authors) 


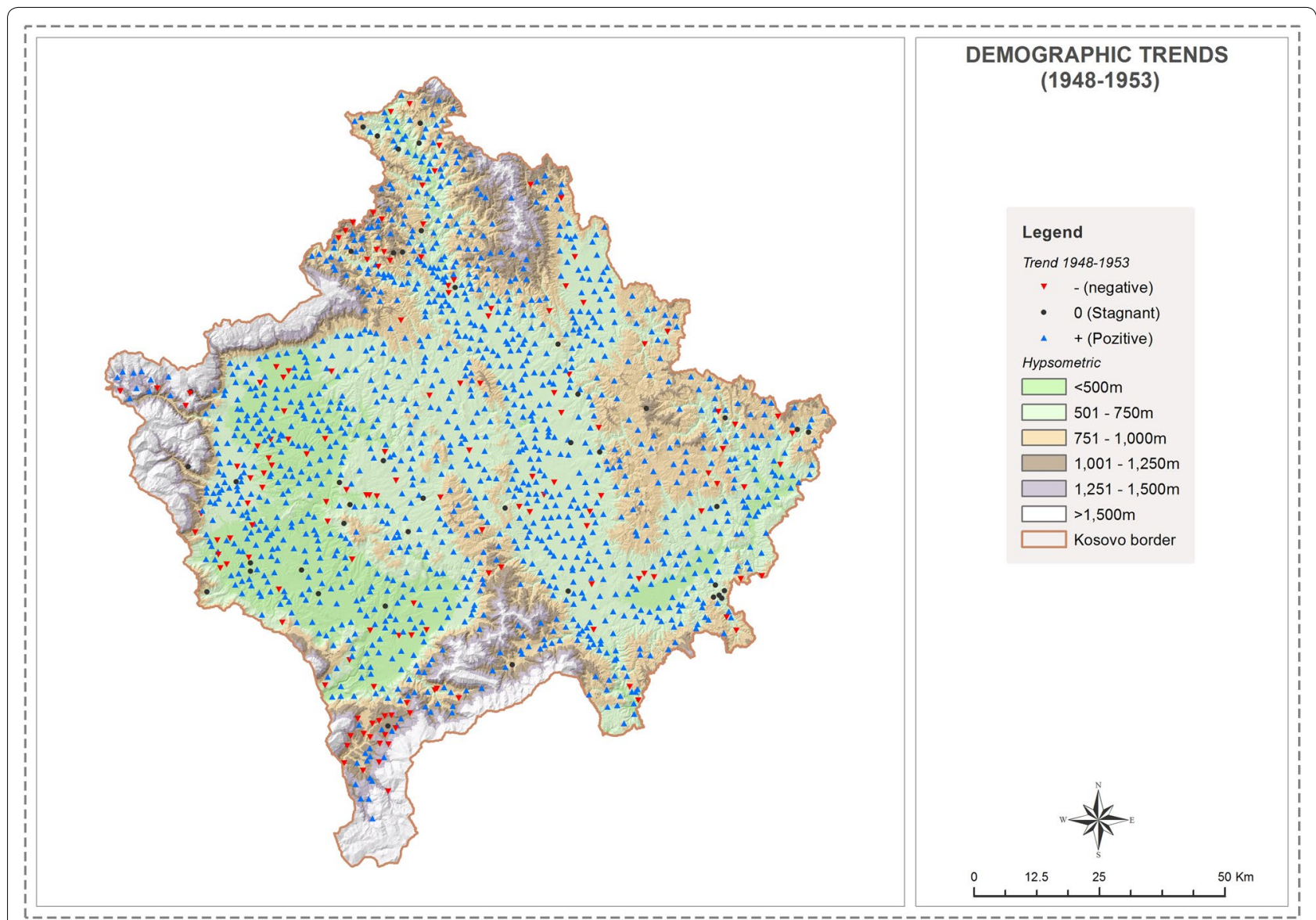

Fig. 4 The population trends by settlements in Kosovo for the period 1948-1953 (by authors)

In the 2011 census the situation is as follow: dominate the smaller settlements <500 inh with $49.39 \%$, then all other settlements mark the growing except number of large group of settlements or settlements with more than $50,000 \mathrm{inh}$. This change is a result of changes in boundaries affecting large urban areas (city of Mitrovica is divided in two part, in the south and north).

Regarding the density of settlements under hypsometric and time periods, generally at the national level the situation is continuing mainly without any changes and continuously there is $13 \mathrm{set} / \mathrm{km}^{2}$. The calculation is made using the following formula: ${ }^{1}$

$$
D=\frac{n .100}{S}
$$

$D$ settlement density, $n$ number of settlements, and $S$ surface in $\mathrm{km}^{2}$.

\footnotetext{
${ }^{1}$ M. Radovanović, S. Nikolić, "Disperzija kao kvantitativni parameter prostornog razmeštaja i metode za izučavanje seoskih naselja", Zbornik radova, GI. Sv.xx. Beograd, 1973, p. 104.
}

What does not change at all censuses is the average density of settlements which has consistently been around 13 settlements per square kilometer. A similar situation is also in the hypsometric level, for e.g. in the hypsometric zone $<500 \mathrm{~m}$ is about $19 \mathrm{St} / \mathrm{km}^{2}$, then $17 \mathrm{St} / \mathrm{km}^{2}$ from 500 to $750 \mathrm{~m}$ of hypsometry, while in 750 to $1000 \mathrm{~m}$ is about $9 \mathrm{St} / \mathrm{km}^{2}$. The hypsometric zone that shows increase of settlement density is $1000-1250 \mathrm{~m}$ from 9.53 $\mathrm{St} / \mathrm{km}^{2}$ to $10.19 \mathrm{St} / \mathrm{km}^{2}$ because fragmented part of disperse settlement became a new settlement itself, while in the hypsometric zone 1250-1500 m marked decline from $3.70 \mathrm{St} / \mathrm{km}^{2}$ to $2.34 \mathrm{St} / \mathrm{km}^{2}$, and the last hypsometric zone $>1500$ it has a constant state $0.11 \mathrm{St} / \mathrm{km}^{2}$. So, in general density of settlements is also invariant under hypsometry (Table 3).

Historically about $80 \%$ of Kosovo settlements lie at an altitude $<750 \mathrm{~m}$, where the majority of them belong to range size up to 2500 inh.

Trends in growth, reduction and stagnation of population in settlements from previous population census show that the number of settlements that have shown negative trend of the population has grown consistently, 


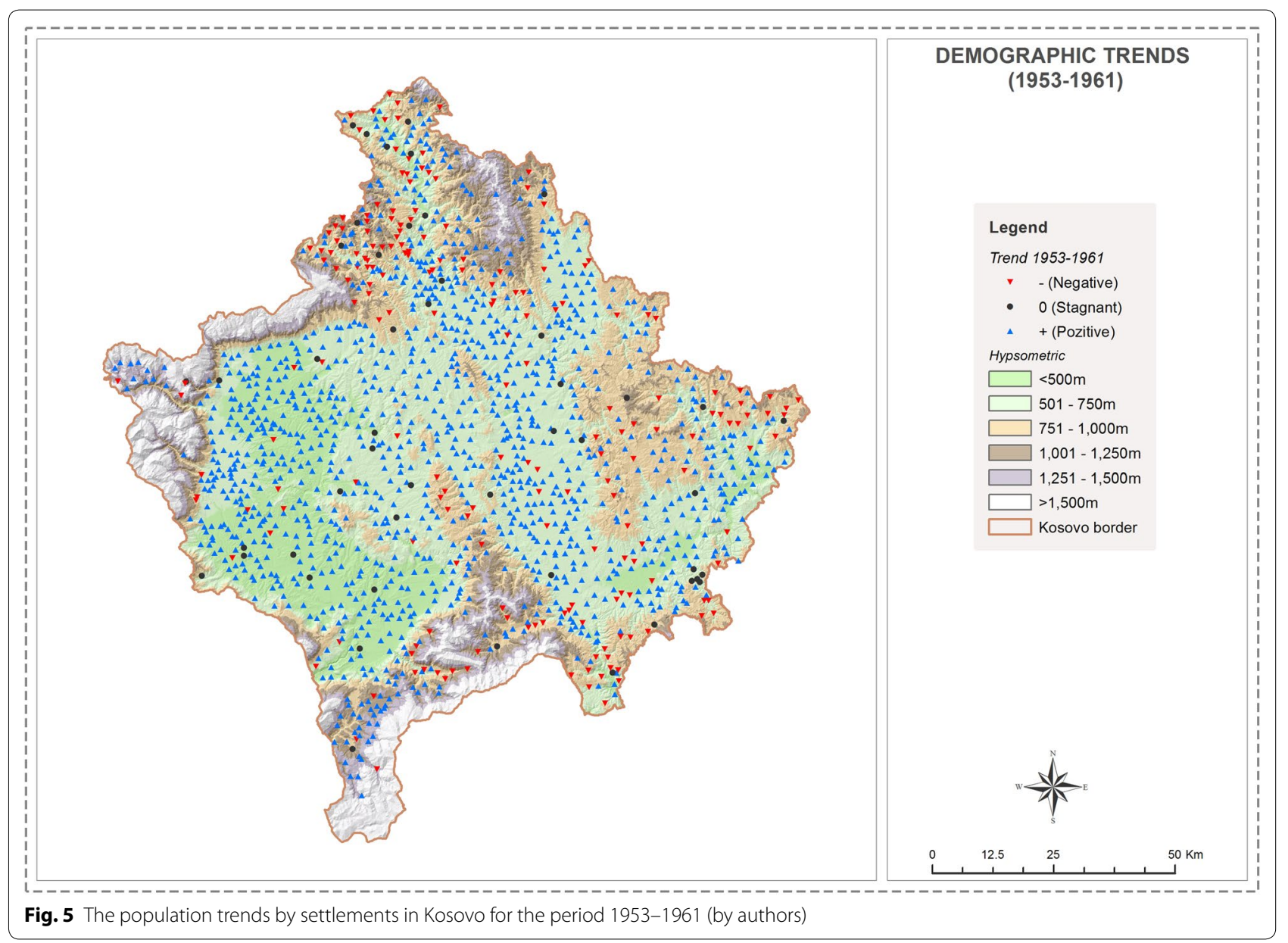

and opposition to this category are settlements that have increased the number of population, while settlements with stagnation trend growth until the census of 1961, then decline. Settlements with negative population trend are as follows; from 144 settlements in the period 1948-1953; 198 settlements in the period 1953-1961; 283 settlements in 1961-1971; 405 settlements in the period 1971-1981; and 800 settlements in the period 1981-2011. While settlements that marked positive trend continually reduced, by 1280 settlements in the period 1948-1953; in 1221 settlements in the period 1953-1961; then 1145 settlements in 1961-1971; 1025 settlements in the period 1971-1981; and 661 settlements in the period 1981-2011. Changes in negative or positive trends magnify themselves occur mainly in settlements that lie on the first three hypsometric zones, namely in the hypsometric zone $<500,500-750$ and $750-1000 \mathrm{~m}$, and trends periods which has changed mostly is 1981-2011. The reasons for this are mainly the difficult conditions of life, the very limited number of social services and utilities, extreme low level of capital investment in infrastructure, the lack of prospects in the primary sector, the opportunity to migrate to settlements that lies in plains with plenty arable land and cities, and as well as migration abroad in order to ensure the welfare and long-term perspective for a family because of the state of frozen conflict-war in Kosovo during 1989-1999. In general, many of these factors are known as repulsive factors manifested by the removal of the population from agriculture and attractive factors that attract agricultural population in other economic activities Ramadani 2016.

The trend was calculated with a simple formula: ${ }^{2}$

$$
\mathrm{P}_{\mathrm{t}}=\mathrm{P}_{1}-\mathrm{P}_{0}
$$

$P_{t}$ is the population trend for given period of time; $P_{0}$ is the first population state of given time; $P_{1}$ is the second population state of given time (Figs. 3, 4, 5, 6, 7, 8).

\footnotetext{
2 The authors (R. Murseli and H. Dana) designed the formula for the purpose of this research.
} 


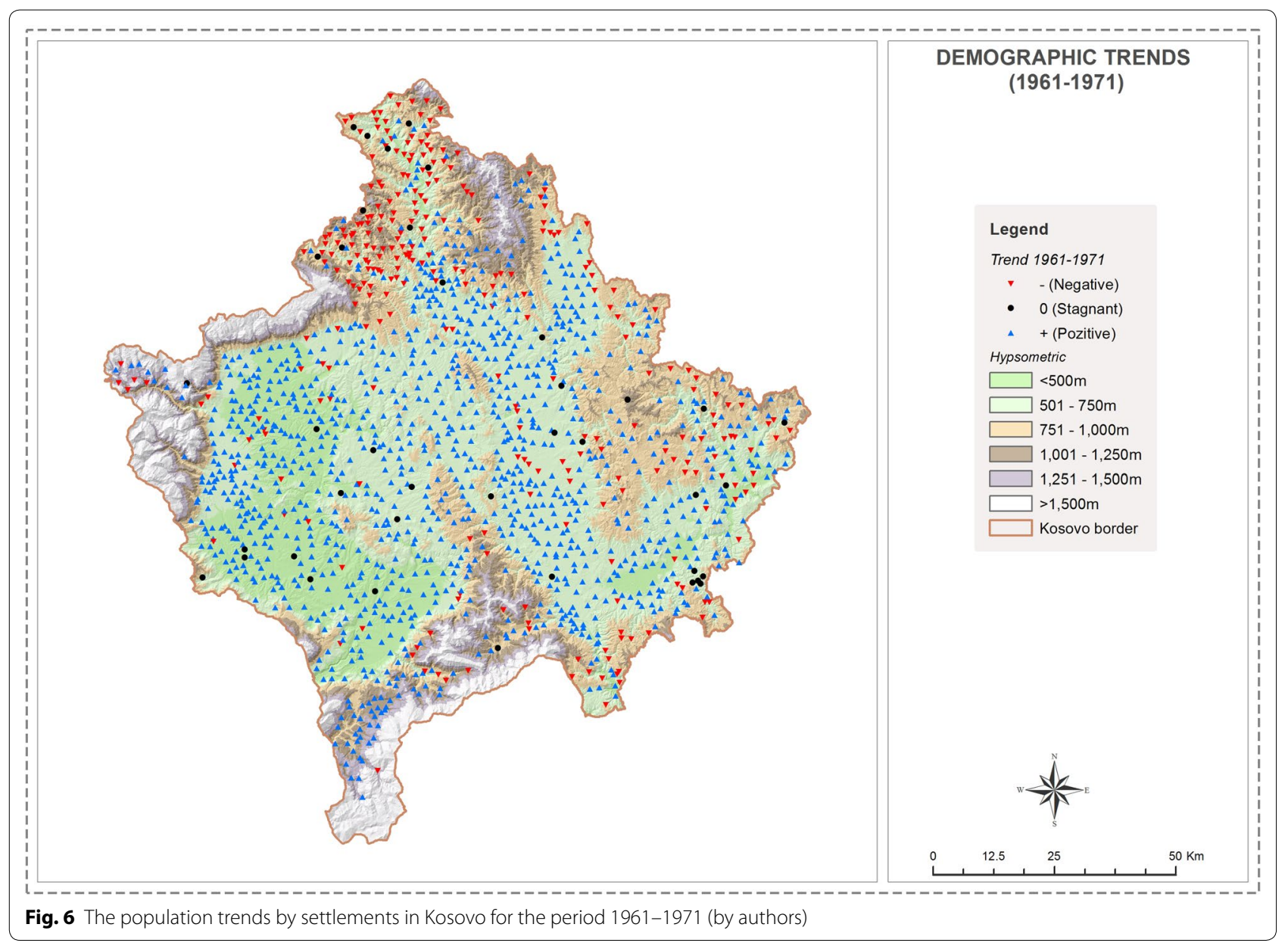

\section{Population and hypsometry}

Lowest hypsometric zones $<500 \mathrm{~m}$ and 500-750 have shown a continuous increase of population while others $>750 \mathrm{~m}$ shown a periodical grown, some until 1971 and others until 1981 and after these two periods marked population decline. In general, there is a legality, with increasing altitude decreases the number of the population in relation to the surface (Table 4).

Hypsometric zones with greater pressure of population have been and are the lowest quintile, respectively the first two zones $<500 \mathrm{~m}$ and $500-750 \mathrm{~m}$ where by all censuses have lived continuously over $80 \%$ of the total population of Kosovo. According to the census of 1948 up to $750 \mathrm{~m}$ of altitude lived $84.25 \%$ of the total population of Kosovo at $57.26 \%$ of the total territory, while in 2011 at the same altitude or hypsometric zone lived 95\% of the total population of Kosovo. Hypsometric zone which is narrowed in demographic terms is the third level or hypsometric zone 750-1000 m (Table 5).

The main causes of reducing the number of population above second hypsometric zone are mainly shortage of arable land, reducing the proportion of people due to the lack of essential services, very low degree of public capital investment. While the swelling population in two first hypsometric zones is due to the much better conditions such as terrain is mainly field, agricultural land is in high quality, good access to the education, health and security services and proximity to local and regional malls and markets. In these circumstances exist a displacement of population within a mini-mezzo geographical territory in which the population migrates towards the lowland areas. This type of migration we call it "gravitational migration" of the population (Fig. 9).

Based on the data presented in Table 2. Kosovo's population for the period of 1948-2011 (63 years) increased to $1,046,947$ inh or 16,618 inh per year, while the number of settlements has increased from 1437 as they were in 1948-1468 in 2011. Meanwhile, the population density continuously increased by increasing the number of the total population, which in 1948 was $67.22 \mathrm{inh} / \mathrm{km}^{2}$ while in 2011 it increased to $163.23 \mathrm{inh} / \mathrm{km}^{2}$, for i.e. for 63 years has grown to $96.01 \mathrm{inh} / \mathrm{km}^{2}$.

The curve indexes indicate in which period the changes begun, and by listing the basic census period 1971-1981 


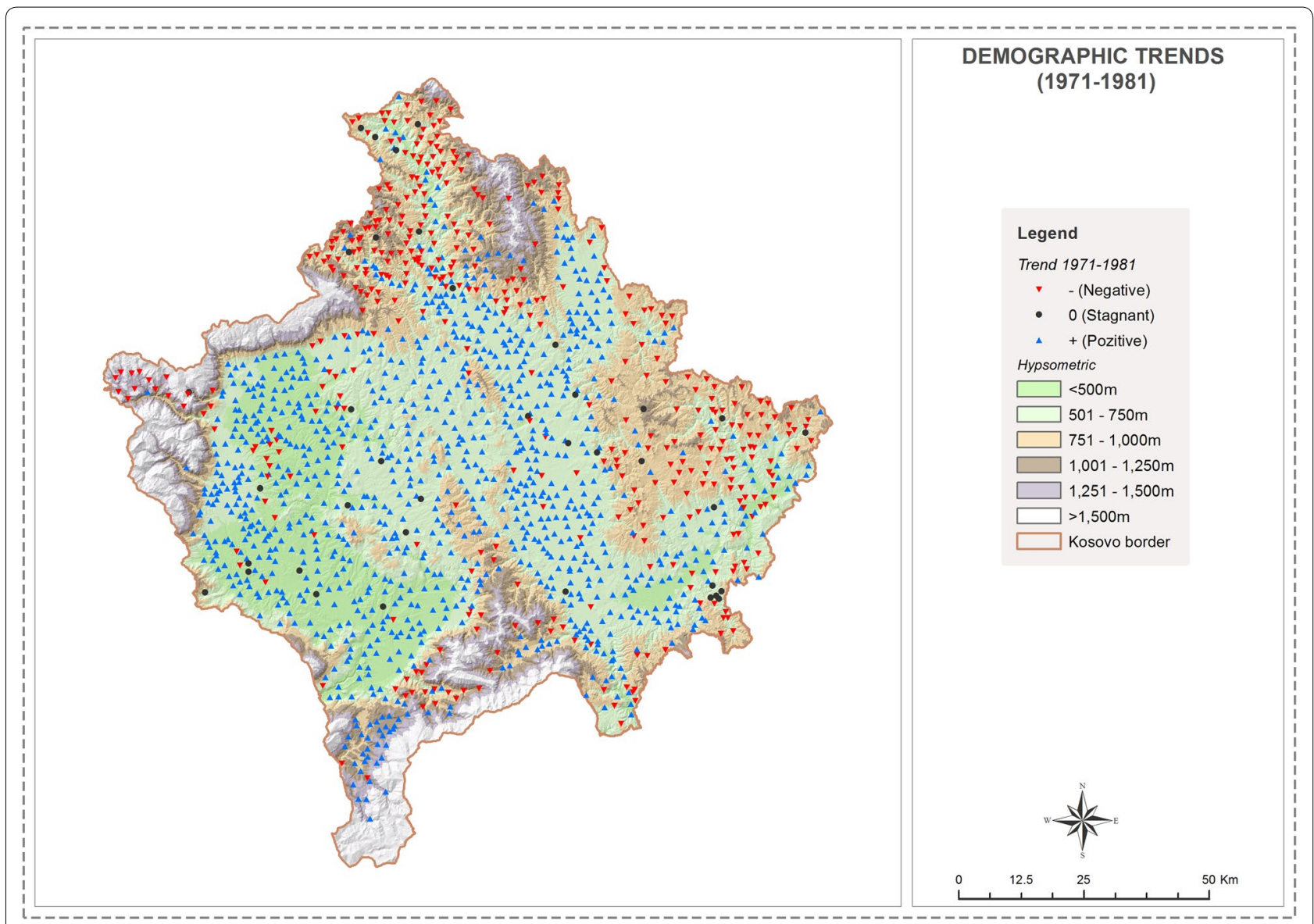

Fig. 7 The population trends by settlements in Kosovo for the period 1971-1981 (by authors)

is the beginning of population trend decline for many hypsometric zones $>750 \mathrm{~m}$.

Basic index curve varies depending on hypsometry and time period. For e.g. the first two hypsometric zones $<500 \mathrm{~m}$ and $500-750 \mathrm{~m}$ in the basic index curve are continuously increasing, while for hypsometric zones $>750 \mathrm{~m}$ basic index curve is increased up to 1971, namely 1981 and then declined to some zones it shows even the drastic drop.

Formula: ${ }^{3}$

$$
B i=\frac{X_{n}}{X_{0}} \cdot 100
$$

where $X n$ is the continues number or member range, while $X_{0}$ is the first and base member and it has constant value of 100 (Fig. 10).

While the curves of ranking index for hypsometric zone are changing though with a tendency to trend decline from previous periods, e.g. hypsometric zone
$>1500 \mathrm{~m}$ humbled curve starts since 1961, while for most of the hypsometric zone curve decreases of range index started in 1971 and 1981. In this case create a legality, where the higher the hypsometric zone is much early it starts to decline the curve of ranking index.

Formula: ${ }^{4}$

$$
R i=\frac{X_{n}}{X_{n-1}} \cdot 100
$$

where $X_{n}$ is the continues number or member range, while $X_{n-1}$ is the second member and it follows the $X_{n}$ (Fig. 11).

\section{Conclusions}

Based on the results presented in this research with the increase of hypsometry the population decrease and at the same time reduce the resources in general. Since the census in 1948 until the 1971 the population 


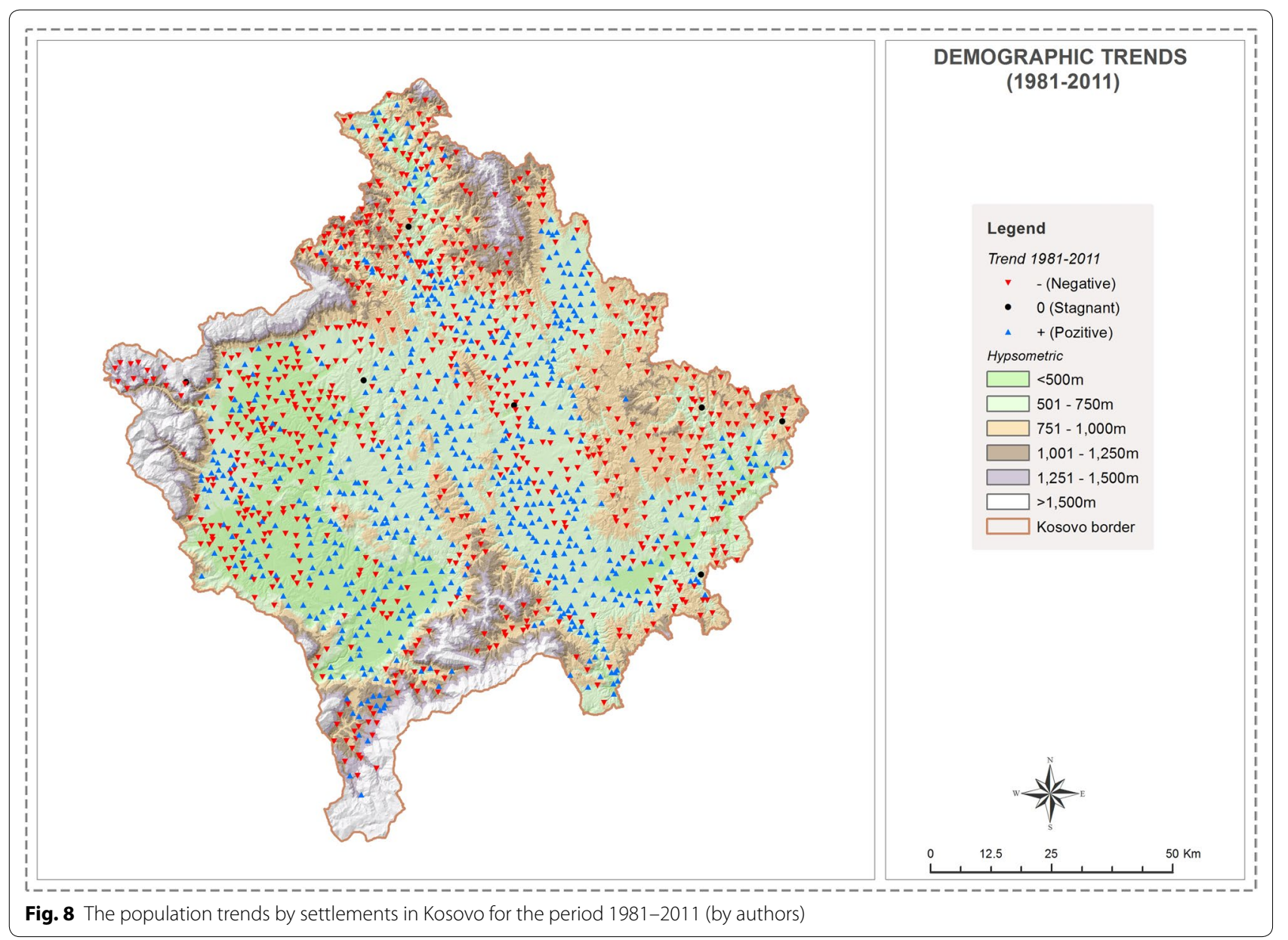

of hypsometric zones $>750 \mathrm{~m}$ has marked a very low increase while after the 1971 census and especially after the 1981 census population decreased drastically. In general, the hypsometric zone which is loaded mostly by the "gravitational migration" of population is the hypsometric zone $500-750 \mathrm{~m}$ where $53.5 \%$ of Kosovo settlements stretch. This zone poses also the overwhelmingly agricultural land fund (41.09\%) especially for central and eastern part of Kosovo.

Based on the facts elaborated above it can be concluded that there are three major flaws in demographic hypsometry of Kosovo:

(1) population of rural mountainous or high hypsometric zones $>750 \mathrm{~m}$ tends continuously to move into lowest hypsometric zones, mainly in the second zone 500-750 m;

(2) the rate of discharge settlements from hypsometric zones $<500 \mathrm{~m}$ and $500-750 \mathrm{~m}$ was high mainly because of migration within the same zone but in urban areas or largely cities, and

(3) the rate of discharge settlements from all hypsometric zones was high mainly because of migrated to the third countries.

If these trends continue in the future where the agricultural land continuously reduce from population growth and urban expansion in general and the construction of network infrastructure then general fund of arable land resources, agricultural land per capita, and the possibility of Kosovo to raise funds and yields of agricultural products will be much more limited. These trends lead to the unavoidable conflict between the continuous tendency of agricultural land reduction and urban expansion that will create a permanent conflict in the first two hypsometric zones. Of course, in these conditions suggestion is to achieve sustainable policies, integrated protection of agricultural land, to achieve the sustainable 
Table 4 Population according hypsometry and population censuses (by authors)

\begin{tabular}{|c|c|c|c|c|c|c|c|}
\hline Hypsometric classes & Sip. $\mathrm{km}^{2}$ & 1948 & 1953 & 1961 & 1971 & 1981 & 2011 \\
\hline$<500 \mathrm{~m}$ & 1763.10 & 188,027 & 210,057 & 250,105 & 329,379 & 436,423 & 504,992 \\
\hline $500.01-750 \mathrm{~m}$ & 4481.10 & 429,616 & 482,294 & 583,818 & 772,317 & 1007,162 & 1185,796 \\
\hline 750.01-1000 m & 2350.71 & 77,470 & 83,463 & 87,833 & 93,522 & 87,341 & 46,518 \\
\hline $1000.01-1250 \mathrm{~m}$ & 912.60 & 28,770 & 30,792 & 32,813 & 37,708 & 41,580 & 32,407 \\
\hline $1250.01-1500 \mathrm{~m}$ & 513.75 & 9041 & 9179 & 9219 & 10,574 & 11,728 & 10,298 \\
\hline$>1500 \mathrm{~m}$ & 883.90 & 150 & 157 & 194 & 202 & 159 & 10 \\
\hline Total & 10,905 & 733,074 & 815,942 & 963,982 & 1243,702 & 1584,393 & 1780,021 \\
\hline
\end{tabular}

Table 5 Population increased or decreased by period of time and hypsometry (by authors)

\begin{tabular}{lcrrrr}
\hline Hypsometry/years & $\mathbf{1 9 4 8 - 1 9 5 3}$ & $\mathbf{1 9 5 3 - 1 9 6 1}$ & $\mathbf{1 9 6 1 - 1 9 7 1}$ & $\mathbf{1 9 7 1 - 1 9 8 1}$ & $\mathbf{1 9 8 1 - 2 0 1 1}$ \\
\hline$<500$ & 22,030 & 40,048 & 79,274 & 107,044 & 68,569 \\
$500-750$ & 52,678 & 101,524 & 188,499 & 234,845 & 178,634 \\
$750-1000$ & 5993 & 4370 & 5689 & -6181 & $-40,823$ \\
$1000-1250$ & 2022 & 2021 & 4895 & 3872 & -9173 \\
$1250-1500$ & 138 & 40 & 1355 & -154 & -149 \\
$>1500$ & 7 & 37 & 8 & -43 &
\end{tabular}

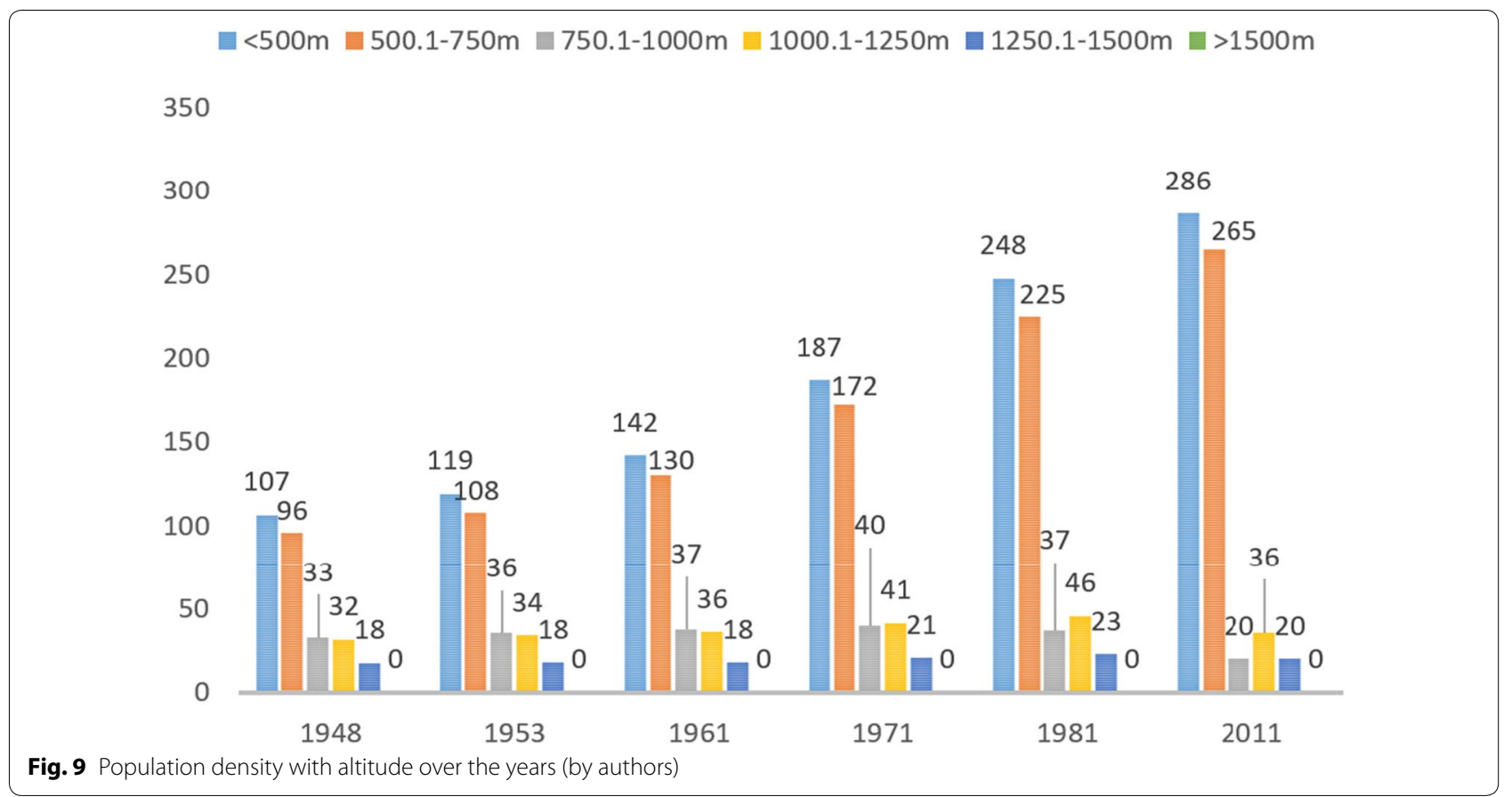

management of the environment, as well as integrated and balanced spatial-urban planning and development, to support sustainable densification of urban areas, and urban expansion into areas or locations that do not conflict with environmental protection policies and the loss of agricultural land. 


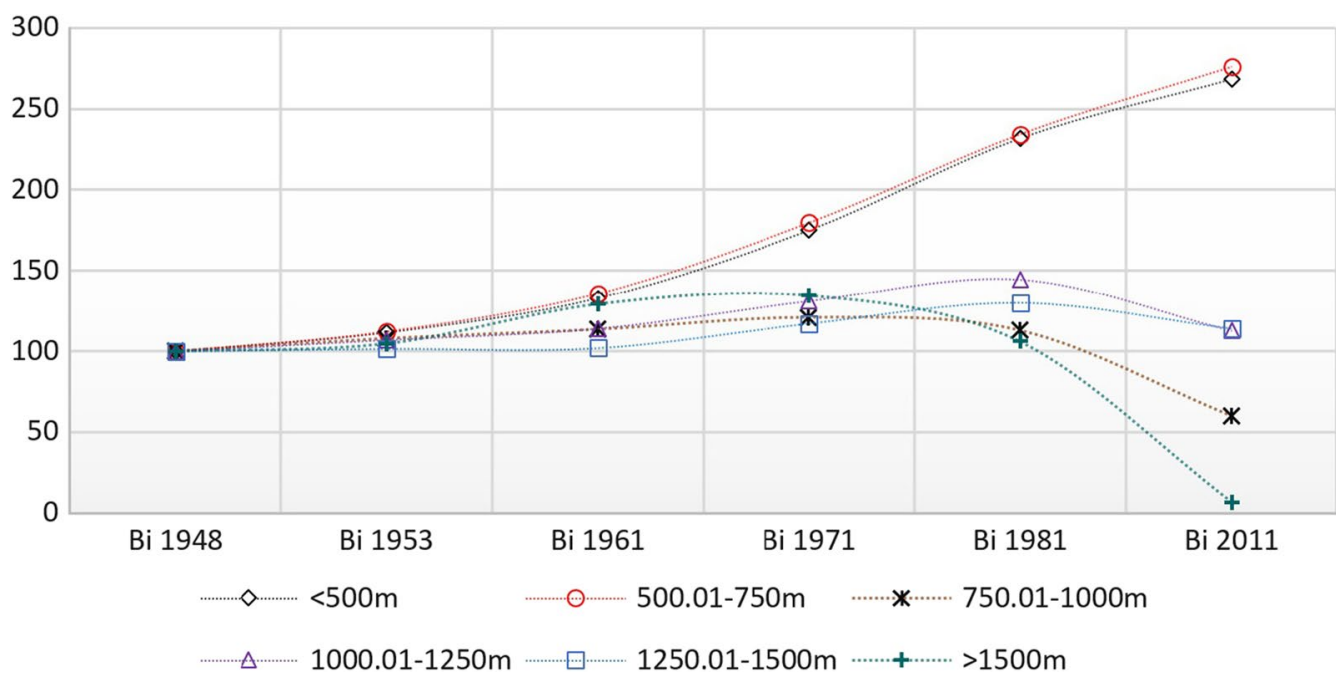

Fig. 10 Basic index (by authors)

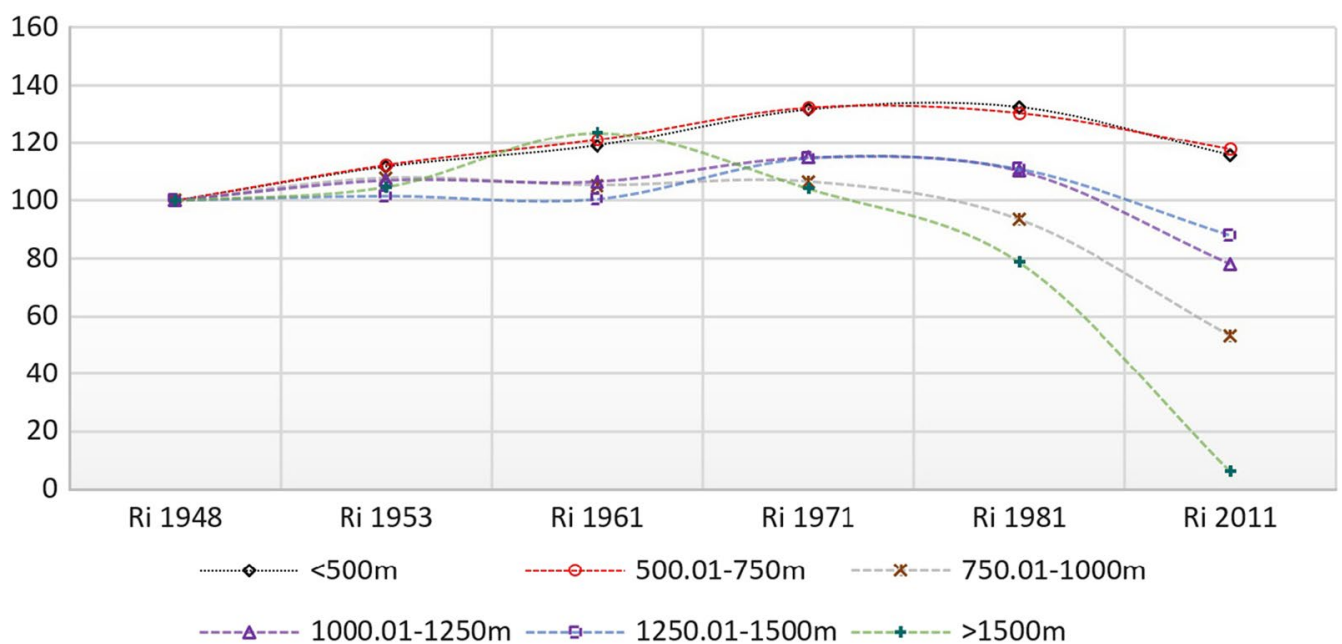

Fig. 11 Range index (by authors)

\section{Authors' contributions}

RM set up the idea of this research and performed all necessary analysis, maps and other graphic content of the research. Working as a Spatial Planner and GIS expert at the Institute of Spatial Planning in Kosovo for more than 12 years where the chances of applying geographical knowledge are unlimited has helped very much to address many qualitative issues within this paper research. HD participated in its design and coordination and helped to draft the manuscript. Both authors read and approved the final manuscript.

\section{Acknowledgements}

We would like to acknowledge the Kosovo Agency of Statistics that provided the date in GIS format for all settlements of Kosovo according to censuses. We would like to thank especially Mr. Idriz Gashi.

\section{Competing interests}

The authors declare that they have no competing interests.
Received: 18 July 2016 Accepted: 7 October 2016

Published online: 10 November 2016

\section{References}

ASTER Global Digital Elevation Model (GDEM) version 2. http://www.jspacesystems.or.jp/ersdac/GDEM/E/4.html. Accessed 03 Oct 2011

Centroid of Kosovo Settlements (GIS) of population censuses of 1948. Kosovo Agency of Statistics, Prishtinë 2014

Centroid of Kosovo Settlements (GIS) of population censuses of 1953. Kosovo Agency of Statistics, Prishtinë 2014

Centroid of Kosovo Settlements (GIS) of population censuses of 1961. Kosovo Agency of Statistics, Prishtinë 2014

Centroid of Kosovo Settlements (GIS) of population censuses of 1971. Kosovo Agency of Statistics, Prishtinë 2014 
Centroid of Kosovo Settlements (GIS) of population censuses of 1981. Kosovo Agency of Statistics, Prishtinë 2014

Centroid of Kosovo Settlements (GIS) of population censuses of 2011. Kosovo Agency of Statistics, Prishtinë 2014
Pushka A (1985) Quantitative Methods in Geography. University of Prishtina, Prishtinë, p 25

Ramadani I (2016) 'Settlements of Kosovo'—spatial and functional organizations. Libri Shkollor, Prishtinë
Submit your manuscript to a SpringerOpen ${ }^{\mathcal{O}}$ journal and benefit from:

- Convenient online submission

- Rigorous peer review

- Immediate publication on acceptance

- Open access: articles freely available online

- High visibility within the field

- Retaining the copyright to your article

Submit your next manuscript at $>$ springeropen.com 